\title{
Patterns of arboreal and terrestrial space use by non-volant small mammals in an Araucaria forest of southern Brazil
}

\author{
MAURY S.L. ABREU ${ }^{1}$ and LARISSA R. DE OLIVEIRA ${ }^{1,2}$ \\ ${ }^{1}$ Laboratório de Ecologia de Mamíferos, Universidade do Vale do Rio dos Sinos/UNISINOS, \\ Av. Unisinos, 950, Centro 2, bloco D, sala 2D221, 93022-000 São Leopoldo, RS, Brasil \\ ${ }^{2}$ Grupo de Estudos de Mamíferos Aquáticos do Rio Grande do Sul/GEMARS, \\ Av. Tramandaí, 976, 95625-000 Imbé, RS, Brasil
}

Manuscript received on February 20, 2013; accepted for publication on October 14, 2013

\begin{abstract}
Despite the advances in the techniques for researching arboreal small mammals, detailed ecological data, such as habitat use patterns, are practically nonexistent for many species. Using 150 live-traps installed on the ground, understory $(1.0-5.0 \mathrm{~m})$ and canopy $(>5.0 \mathrm{~m})$ we investigated patterns of arboreal and terrestrial space use by small mammals in an Araucaria Forest in southern Brazil (29²9'08'S; 50¹2'26'W). We also measured 19 microhabitat variables that could potentially influence the abundance of such mammals on each trap station. The results indicated that Akodon montensis and A. serrensis were mainly terrestrial. Delomys dorsalis was also terrestrial, but it also used understory (17.24\% of captures). Juliomys sp. and Gracilinanus microtarsus were the most arboreal small mammals recorded. A. montensis was associated with dense vegetation, while $A$. serrensis selected positively opened areas. Juliomys sp. and G. microtarsus were associated to microhabitat variables related to the access and movement within the canopy. Moreover, bromeliads on arboreal layer were an important factor for these two arboreal species. This is the first study to report microhabitat associations by Juliomys sp. and A. serrensis, and we demonstrated that vertical stratification and microhabitat use were both synergic mechanisms to determine habitat use by small mammals on the Araucaria Forest of southern Brazil.
\end{abstract}

Key words: Didelphimorphia, microhabitat, neotropical mammals, Rodentia, vertical stratification.

\section{INTRODUCTION}

Similar species that coexist spatially frequently show differences on their feeding strategies, habitat use, or patterns of time use allowing the resource partitioning (Schoener 1974). For the Neotropical non-volant small mammals, studies have indicated different mechanisms of species segregation, especially on diet (Leite et al. 1996), daily activity

Correspondence to: Maury Sayão Lobato Abreu

E-mail:maury.abreu@gmail.com
(Vieira and Baumgarten 1995, Graipel et al. 2003) and space use (Leite et al. 1996, Busch et al. 2001). These mammals occupy a wide variety of habitats with different characteristics, both on the ground and in the upper strata of the forest, and studies have demonstrated that the arboreal layers exhibit a unique and diverse small mammal fauna (e.g. Cunha and Vieira 2002, Graipel 2003, Grelle 2003, Vieira and Monteiro-Filho 2003, Graipel et al. 2006). Approximately $62 \%$ of the marsupials and 
small rodents (family Cricetidae) in Brazil have arboreal or scansorial habits (Paglia et al. 2012). The use of arboreal layers increases the area that could be occupied by the animals (Leite et al. 1996, Cunha and Vieira 2002), providing resources that are not available on the ground (Rader and Krockenberg 2006) and reducing predation by terrestrial predators (Abreu et al. 2010). Despite the advances in the techniques for arboreal survey (e.g. Graipel 2003, Delciellos et al. 2006), detailed ecological data, like habitat use patterns, are practically nonexistent for many species (Kays and Allison 2001).

In general, the rodents from the Tribe Akotontini are more common on the ground, while those from the Tribes Oryzomyini and Thomasomyini frequently present a generalist or arboreal habit (e.g. Graipel 2003, Vieira and Monteiro-Filho 2003, Grelle 2003, Lambert et al. 2005, Graipel et al. 2006, Cademartori et al. 2008, Hannibal and Cáceres 2010). With exception of the semi-aquatic marsupial Chironectes minimus, the terrestrial malsupials Lutreolina crassicaudata, Metachirus nudicaudatus and the species of the genus Monodelphis, all the marsupials on the Brazilian territory present scansorial or arboreal habits (e.g. Graipel 2003, Grelle 2003, Vieira and Monteiro-Filho 2003, Lambert et al. 2005, Graipel et al. 2006, Hannibal and Cáceres 2010, Paglia et al. 2012). Vieira and Monteiro-Filho (2005) suggested that similar-sized species tend to differ in their patterns of vertical utilization of habitat, except for the Akodontini rodents. Similar pattern was also suggested by Charles-Dominique et al. (1981) in French Guiana.

In addition to vertical stratification, microhabitats use also explains space use and distribution of the small mammal species in the Neotropical forests (e.g. Murúa and González 1982, Lacher Jr and Alho 1989, Vieira et al. 2005, Püttker et al. 2008, Dinucci et al. 2008, Naxara et al. 2009, Lima et al. 2010, Sponchiado et al. 2012). These studies searched for associations between species occurrence and the vegetation structure, which could be related to resource availability, predation risk and other important aspects of the ecology of small mammals. Differences between species related to microhabitat use can potentially reduce interspecific encounters, decreasing the effect of competition and facilitating coexistence of small mammals (e.g. Dalmagro and Vieira 2005). The majority of the studies on microhabitat associations by these mammals are restricted to terrestrial or scansorial species, with little information about arboreal species.

In a mosaic of swamp and upland forests in French Guiana, Adler et al. (2012) showed that the arboreal rodent Oecomys rutilus was associated with lianas, while the arboreal marsupial Micoureus demerarae was associated to the number of logs. In the Araucaria Forest of southern Brazil, Cademartori et al. (2008) found positive correlation between the captures in the arboreal layers and the canopy cover, but they did not analyze the species individually. For others Neotropical small mammal species ecological data is limited. For example, the rodents of the genus Juliomys are considered highly arboreal (Vieira and Monteiro-Filho 2003, Prevedello et al. 2008, Cademartori et al. 2008), but detailed information about their ecology, like microhabitat use, are very scarce.

The Araucaria Forest (Ombrophilous Mixed Forest) of southern Brazil is a subtropical forest type included in the domain of the Brazilian Atlantic Forest. It originally occupied about $200,000 \mathrm{~km}^{2}$ of the Brazilian territory, but it was reduced to only 2 to $5 \%$ of its original area (Mähler Junior and Larocca 2009). The Araucaria Forest is characterized by the presence of Araucaria angustifolia, typical species of the Ombrophilous Mixed Forest, being considered an important food resource for small mammals (Iob and Vieira 2008). There are no mammalian species exclusively recorded to the 
Araucaria Forest, but by adding components of the southeastern Atlantic Forest and species with most austral distribution, the Araucaria Forest has an unique mammalian fauna, with at least 20 species of didelphid marsupials and 27 species of small rodents (family Cricetidae). There is also strong evidences of the occurrence of species that have not been formally described by science, including rodents from the genera Juliomys, Scapteromys and Deltamys (Ribeiro and Vieira 2012). Little information was published on the patterns of habitat use by small mammals in the Araucaria Forest. Cademartori et al. (2008) were the only ones to study vertical stratification of small mammals in these forests. They found that Akodontini rodents (Akodon montensis and Brucepattersonius iheringi) occurred on the ground, and the Oryzomini rodents (Oligoryzomys nigripes and Sooretamys angouya) used arboreal and terrestrial layers. In relation to the microhabitat use, the study of Dalmagro and Vieira (2005) was the only one held in the Araucaria Forest of southern Brazil.

In this paper, we investigated the patterns of the use of arboreal and terrestrial space by non-volant small mammals in an Araucaria Forest of southern Brazil. With this, we addressed the following questions: (i) How do the species segregate in relation to vertical stratification? (ii) Which microhabitat variables are most important to determine the occurrence of the most abundant species?

\section{MATERIALS AND METHODS}

\section{STUDY AREA}

We conducted our research in the Center for Research and Nature Conservation Pró-Mata ("Centro de Pesquisas e Conservação da Natureza" Pró-Mata), a private preservation area that covers about 4500 ha in the northeastern of the state of Rio Grande do Sul, Brazil (29²9’08' S; $50^{\circ} 12^{\prime} 26^{\prime \prime} \mathrm{W}$ ) (Fig. 1). Its altitude is between 600 $\mathrm{m}$ to $900 \mathrm{~m}$ above the sea level and the climate is markedly seasonal and mesothermic, with annual average temperature of $14.5^{\circ} \mathrm{C}$ and annual average rainfall of $2252 \mathrm{~mm}$. The vegetation landscape includes Ombrophilous Mixed Forest (Araucaria Forests), Highland fields and Ombrophilous Dense Forest. For a detailed description of the area see Iob and Vieira (2008). Our sample grid was inserted in an initial transition region between the Ombrophilous Mixed Forest (Araucaria Forest), to the Ombrophilous Dense Forest, with the presence of Araucaria angustifolia in lower density than in other Araucaria Forests of the region.

\section{TRAPPING PROCEDURES}

Small mammals were sampled seasonally, with one capture in each session: austral summer, autumn, winter and spring 2011. Each one consisted of six nights of sampling, totalizing 24 sampling nights. We used two sizes of Sherman ${ }^{\circledR}$ (large, $11 \mathrm{~cm}$ x $12.5 \mathrm{~cm} \mathrm{x} 37 \mathrm{~cm}$, and small, $9 \mathrm{~cm}$ x $9.5 \mathrm{~cm} \mathrm{x}$ $23 \mathrm{~cm}$ ) and Tomahawk ${ }^{\circledR}$ live-traps (large, $14 \mathrm{~cm}$ x $14 \mathrm{~cm} \mathrm{x} 33 \mathrm{~cm}$, and small sizes, $11 \mathrm{~cm} \mathrm{x} 10$ $\mathrm{cm} \times 23 \mathrm{~cm}$ ). Each trap was baited with one of the following types of bait: a mixture of mashed banana, corn meal, commercial cod-liver oil, and vanilla essence, or small pieces of cubed bacon. We used these two different types of bait expecting to increase the number of species attracted. The different trap types, trap sizes and bait types were equally distributed among the layers (see below), and randomly along the grid.

We established a sampling grid of 3.24 ha with 100 trap stations ( $10 \times 10$ configuration), $20 \mathrm{~m}$ distant from each other. During each sampling session we placed 50 traps on the ground, 50 in the understory and 50 in the canopy (using suspended platforms, as proposed by Vieira and Monteiro-Filho (2003) on randomly selected trap stations. For our study, we considered the understory as the space between $1 \mathrm{~m}$ and $5 \mathrm{~m}$ high, and as the canopy all the space above $5 \mathrm{~m}$ high. The majority of canopy traps (70\%) were between 8 and $10 \mathrm{~m}$ height, with the highest at $12 \mathrm{~m}$ and the lowest at $6 \mathrm{~m}$. 


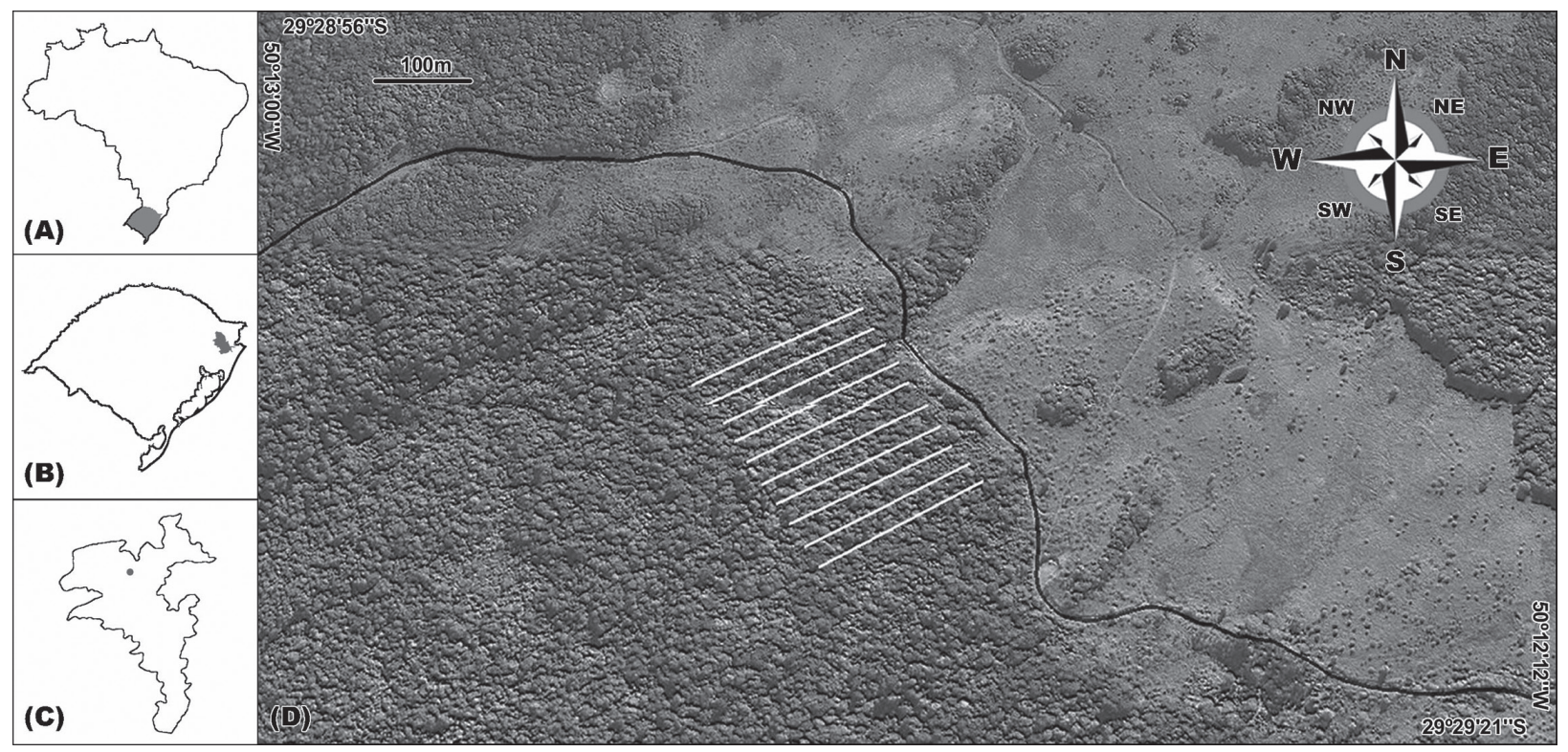

Fig. 1 - Study area. (A) Brazilian map, with the state of Rio Grande do Sul in gray; (B) Map of the state of Rio Grande do Sul, with the area of São Francisco de Paula city in gray; (C) Total area of the Pró-Mata, with gray point indicating the sampling area; (D) Satellite photographic image of the sampling grid (white lines represent the lines of the grid and black line represent the road). Font: Google Earth 6.1.0.5001 (captured on 18 July 2012).

All animals captured were identified up to the species level (with exception of Juliomys sp., and a juvenile rodent) based on external morphology, marked with ear-tags (National Band and Tag Co, Newport, KY, USA) and released in the same trap station following the recommendations of the American Society of Mammalogists (Sikes et al. 2011), (capture and collection authorization, SISBIO number 23791-1). At least one specimen of each species was collected and deposited in the Mammal's Collection of "Universidade Luterana do Brasil" (Ulbra), Canoas, state of Rio Grande do Sul, Brazil. Every time that a small mammal was captured, we moved the trap to another station that had no trap during the sampling session. This procedure was adopted for traps in the three layers, but always keeping in the same layer (for example, a trap in the canopy was always moved to the canopy of another trap station). We did this in order to reduce individual recaptures and to increase the number of trap stations sampled during each sampling session (Vieira and Monteiro-Filho 2003,
Dalmagro and Vieira 2005). All trap stations with canopy above $6 \mathrm{~m}$ had a platform to canopy survey (totaling 95 trap stations).

Microhabitat VARIABLES

To verify species associations with microhabitat we measured 19 microhabitat variables that could potentially influence the spatial distribution of small mammals. In this sense, in the field, each trap station was divided in four quadrants of $25 \mathrm{~m}^{2}$ and, in each quadrant we measured the following microhabitat variables during the summer (February 2011) and during the winter (August 2011): (i) percentage of plant cover on the ground $(\% \mathrm{PC})$, considering only the vegetation lesser than $10 \mathrm{~cm}$ high; (ii) percentage of litter cover on the ground (\%LG), measured only in the center of each quadrant; (iii) percentage of uncovered soil (\%US), with no vegetation, including rocks; horizontal obstruction on three heights: (iv) $0.5 \mathrm{~m}$ (OB1), (v) $1.0 \mathrm{~m}$ (OB2), and (vi) $1.5 \mathrm{~m}$ (OB3); (vii) percentage of canopy cover (CAC); (viii) litter depth (LDP); (ix) 
distance of the nearest tree with diameter at breast height (d.b.h.) between $3 \mathrm{~cm}$ and $10 \mathrm{~cm}$ (T03); (x) distance of the nearest tree with d.b.h. $>10 \mathrm{~cm}$ (T10); (xi) number of potential shelters (e.g. ground holes, rock crevices, and fallen log holes) (SHE); number of bromeliads (family Bromeliaceae) on three heights: (xii) up to $1.0 \mathrm{~m}$ (BR1), (xiii) from $1.1 \mathrm{~m}$ to $5.0 \mathrm{~m}$ (BR2) and (xiv) above $5.0 \mathrm{~m}$ (BR3).

For the variables \% $\mathrm{PC}, \% \mathrm{LG}, \% \mathrm{US}$, OB1, OB2 and OB3 we used a square wooden frame $(0.5 \times 0.5 \mathrm{~m})$ divided in 25 open squares by wire mesh (every open square represents $4 \%$ ). The methodology that we used was described by Freitas et al. (2002) with some modifications with regards to the square size. We were positioned approximately in the center of each quadrants with the square wooden frame oriented to the opposite direction of the trap station. For the canopy cover (CAC) we used four digital photographic images of the canopy (one from each quadrant) transformed to a white and black image, and we used the Gap Light Analyser program (Frazer et al. 1999) to verify the proportions of black pixels (no light penetration) in relation to white pixels (light penetration). The litter depth was measured with a wooden stick graduated to each centimeter (Dalmagro and Vieira 2005).

We also measured the following microhabitat variables considering all the area formed by the four quadrants, only during the summer (February 2011): (xv) canopy height (CAH), exactly above the trap station, measured visually using a wooden stick as reference; number of tree and shrubs with d.b.h.(xvi) between 2.0 and $10.0 \mathrm{~cm}$ (NT1), (xvii) between 10.1 and $20.0 \mathrm{~cm}$ (NT2), (xviii) 20.1 and $40.0 \mathrm{~cm}$ (NT3), and (xix) d.b.h. > $40.0 \mathrm{~cm}$ (NT4). Although these variables had been measured only during the summer, they showed no outstanding variability during the study.

\section{DATA ANALYSES}

To verify selectivity in the use of ground, understory and canopy by each species, we compared the observed number of captures with the expected number of captures for each layer, based on the effective trapping effort for each layer (Vieira and Monteiro-Filho 2003, Rader and Krockenberger 2006). Our null hypothesis was that if the small mammals do not select the layer, they should be captured equally in proportion to the trapping effort for each layer. For the species with at least 10 captures during the study, we used the chi-square test to verify significant differences between the observed and the expected captures. For species with less than 10 captures, but at least 5 captures, we pooled the canopy and understory captures and used a Fisher's exact test to compare terrestrial versus arboreal habit. No statistical tests were performed for species with less than 5 captures during the study (including recaptures).

Specifically for Gracilinanus microtarsus we also tested terrestrial versus arboreal captures to verify arboreal habit using Fisher's exact test. For this analysis, we pooled the understory and canopy captures for this species. We also used the Fisher's exact test to verify positive selection for understory or canopy by Juliomys sp. In this case, we removed the ground captures from the analysis. For the other species, we did not make additional tests due to low captures on the arboreal layers.

To verify the microhabitat association, we considered two periods. The first one with the pooled data from the summer and autumn sessions, and the second with pooled data from the winter and spring sessions. Each trap station from the two periods was considered a sampling unit (resulting in 200 sampling units). The variables related to abundance (SHE, BR1, BR2, BR3, NT1, NT2, NT3 and NT4) were transformed as density by square meter (Cerqueira and Freitas 1999). Numeric variables not related to abundance (LDP, T03 e T10) were transformed in the arithmetic mean of the four quadrants for each trap station (Dalmagro and Vieira 2005). For the variables T03 and T10, all quadrants with no value (no tree of that category in the quadrant) were replaced by $5 \mathrm{~m}$. We had to 
do this because these variables represent the spatial dispersion of the trees, and a missing value would disregard the fact that there is no tree of that category on the quadrant. Variables expressed in percentages (\%PC, \%LG, \%US, OB1, OB2, OB3 and CAC) were transformed using arcsine transformation, and after that, we calculated the arithmetic mean of the four quadrants (Zar 1996, Vieira et al. 2005). We did not perform these transformations in the canopy height variable $(\mathrm{CAH})$, and we used the species abundance on each trap station as an index of trap station use. For data independence we used only the first capture of each individual on the analysis of microhabitat association.

We also built a correlation matrix in order to verify inter-correlation between microhabitat variables. The variables \%LG, OB2 and NT1 were discarded of the analysis a priori because they were strongly correlated to other variables $(r>0.5$ or $\mathrm{r}<-0.5$ ). We used only species with at least 5 individuals captured in the analyses. Since the ordination analyzes uses distance measures (Hair Jr et al. 2010), all the trap stations with none small mammal captured were removed.

To reduce the factors to describe the vegetation structure, we used an ordination multivariate analysis, using two matrixes data, one with the small mammals' abundance and another with the microhabitat variables. Detrended correspondence analysis (DCA) of the species and vegetation structure was used to determine whether linear or unimodal ordination methods should be applied (Lepš and Šmilauer 1999). Based on the results obtained in this exploratory analysis, we choose to use a linear method.

We used a redundancy analysis, a constrained ordination method, to verify association between the two matrixes. This analysis combines a regression analysis with a principal components analysis (Borcard et al. 2011), and is based on a biological matrix (small mammals abundance) and an abiotic matrix (microhabitat variables)
(Legendre and Legendre 1998). All the data were transformed by $\log _{10}+1$ for normalization. To verify the significance of the ordination axes, we made 1000 random permutations. In order to quantify the associations between the microhabitat variables and the ordination axes we used Pearson linear correlations.

All the analyses were conducted using the program Project R 2.13.1 (C) 2011 The R Foundation for Statistical Computing) with the vegan package (Oksanen et al. 2011).

\section{RESULTS}

Due to the failure of some traps, our effort was different among layers: 843 trap-nights on the ground, 1090 trap-nights in the understory, and 1114 trap-nights in the canopy. Trapping success also differed among layers $(9.85 \%$ on the ground, $3.39 \%$ in the understory, and $2.51 \%$ in the canopy). We recorded 103 individuals belonging to eight rodent and two marsupial species, with 72 individuals on the ground, 29 individuals in the understory, and 24 individuals in the canopy (Table I).

All captures of Akodon serrensis ( $\chi^{2}=11.33$, d.f. $=2, P=0.003$ ) and Monodelphis dimidiata (Fisher test, $P=0.04$ ) occurred on the ground, while $A$. montensis presented two captures in the understory, but it was a significantly terrestrial rodent $\left(\chi^{2}=29.85\right.$, d.f. $=2$, $P<0.0001)$. The rodent Delomys dorsalis also showed a terrestrial behavior $\left(\chi^{2}=20.45\right.$, d.f. $\left.=2, P<0.0001\right)$, but it used the understory frequently $(17.24 \%$ of the captures occurred in the understory). The rodents Oligoryzomys flavescens (Fisher test, $P=1.0$ ) and Sooretamys angouya (Fisher test, $P=0.59$ ) presented a generalist utilization of the vertical habitat.

On the other hand, the rodent Juliomys sp. was captured only in the upper layers, presenting a totally arboreal behavior $\left(\chi^{2}=7.73\right.$, d.f. $=2$, $P=0.02)$. We found no selection by the canopy or understory (Fisher test, $P=0.29$ ) for this species. The marsupial Gracilinanus microtarsus demonstrated no significant association with the 
TABLE I

Number of individuals captured (number of captures in parenthesis when there were recaptures), total species and total individuals of small mammals in each layer in the study area in the Center for Research and Nature Conservation Pró-Mata, southern Brazil.

\begin{tabular}{lccc}
\hline Species & Ground & Understory & Canopy \\
\hline Didelphimorphia, Didelphidae & & & \\
$\quad$ Gracilinanus microtarsus (Wagner, 1842) & 2 & $9(17)$ & $9(11)$ \\
$\quad$ Monodelphis dimidiata (Wagner, 1847) & 5 & & \\
Rodentia, Cricetidae & & & \\
Akodon montensis Thomas, 1913 & $21(29)$ & 2 & \\
Akodon serrensis Thomas, 1902 & 12 & & \\
Delomys dorsalis (Hensel, 1873) & $20(24)$ & 5 & \\
Juliomys sp. González, 2000 & & 6 & $12(14)$ \\
Oligoryzomys sp. Bangs, 1900 & 1 & & \\
Oligoryzomys flavescens (Waterhouse, 1837) & $2(3)$ & 3 & 2 \\
Oligoryzomys nigripes (Olfers, 1818) & 1 & 2 & \\
Sooretamys angouya (G. Fisher, 1814) & 5 & 2 & 1 \\
Thaptomys nigrita (Lichtenstein, 1829) & 3 & & \\
\hline Total species & 10 & 7 & 4 \\
Total individuals & 72 & 29 & 24 \\
\hline
\end{tabular}

three layers $\left(\chi^{2}=5.27\right.$, d.f. $\left.=2, P=0.07\right)$, but was present in the upper layers more frequently than on the ground (Fisher test, $P=0.04$ ).

The rodent Thaptomys nigrita was also recorded only on the ground. The rodent $O$. nigripes was captured on the ground and in the understory, and an unidentified pup of Oligoryzomys sp. was recorded on the ground. These small mammals' species had less than 5 captures, so, we did not analyze their layer selection.

The redundancy analysis produced eight ordination axes, and the first two accounted for $55.24 \%$ of the variance $(\mathrm{RDA} 1=29.27 \% ; \mathrm{RDA} 2=25.97 \%$, $\mathrm{F}=1.28, P=0.04)$. The first ordination axis represented the density and dispersion of the small trees. Great values to this axis represented areas with abundant and closest small trees. Also, this axis was related to low bromeliad abundance below $1 \mathrm{~m}$, and a high abundance above $5 \mathrm{~m}$ (Table II). The second axis was positively associated to vegetation density on the ground and the canopy cover. Greater values to the second axis represented areas with dense ground vegetation, greater number of large tree, but with an undeveloped canopy cover
(Table II). These large trees were also spaced, which contributed to lower canopy cover. The results indicated that the majority of the small mammals' species was influenced by different microhabitat variables (Fig. 2).

TABLE II

Pearson linear correlations between microhabitat variables and the redundancy axes. RDA1 = first redundancy axis; RDA2 = second redundancy axis. See text for the microhabitat codes.

\begin{tabular}{ccc}
\hline Microhabitat variables code & RDA1 & RDA2 \\
\hline \%PC & -0.416495 & $0.909138^{*}$ \\
\%US & $0.984597 *$ & -0.174837 \\
BR1 & $-0.970021 *$ & 0.243022 \\
BR2 & 0.455543 & -0.890214 \\
BR3 & 0.917562 & 0.397592 \\
CAC & -0.245720 & $-0.969341 *$ \\
CAH & -0.660095 & -0.751182 \\
LDP & -0.889372 & 0.457184 \\
NT2 & $0.983884 *$ & 0.178806 \\
NT3 & -0.952876 & 0.303359 \\
NT4 & 0.655476 & 0.755216 \\
OB1 & -0.923588 & 0.383387 \\
OB3 & -0.450682 & $0.892685 *$ \\
SHE & 0.400132 & $0.916457 *$ \\
T03 & $-0.999548 *$ & 0.030064 \\
T10 & 0.584831 & 0.811155 \\
\hline
\end{tabular}

* Variables with highest correlation values for each axis. 


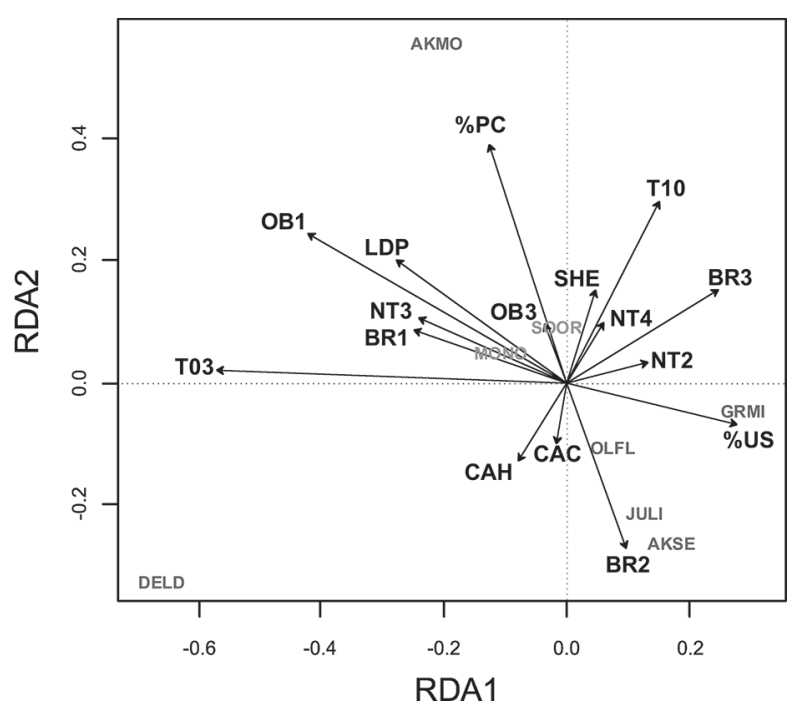

Fig. 2 - Ordination diagram from redundancy analysis of the small mammals' species and microhabitat variables. Species are indicated by codes: AKMO = Akodon montensis; AKSE = Akodon serrensis; DELD = Delomys dorsalis; JULI = Juliomys sp.; GRMI = Gracilinanus microtarsus; $\mathrm{MONO}=$ Monodelphis dimidiata; OLFL = Oligoryzomys flavescens; SOOR $=$ Sooretamys angouya . Microhabitat codes: $\% \mathrm{PC}=$ percentage of plant cover on the ground; \%US = percentage of uncovered soil; BR1 = number of bromeliad plant up to $1.0 \mathrm{~m}$ height; BR2 = number of bromeliad plant between 1.1 and $5.0 \mathrm{~m}$ height; $\mathrm{BR} 3=$ number of bromeliad plant above 5.0 $\mathrm{m}$ height; $\mathrm{CAC}=$ canopy cover; $\mathrm{CAH}=$ canopy height; LDP $=$ litter depth; NT2 = number of trees and shrubs with d.b.h. between 10.1 and $20.0 \mathrm{~cm}$; NT3 = number of trees and shrubs with d.b.h. between 20.1 and $40.0 \mathrm{~cm}$; NT4 = number of trees and shrubs with d.b.h. above $40.0 \mathrm{~cm}$; OB1 = horizontal obstruction at $0.5 \mathrm{~m}$; $\mathrm{OB} 3=$ horizontal obstruction at $1.5 \mathrm{~m}$; $\mathrm{SHE}=$ number of potential shelters; $\mathrm{T} 03=$ distance of the nearest tree with d.b.h. between 3 and $10 \mathrm{~cm}$; T10 = distance of the nearest tree with d.b.h. greater than $10 \mathrm{~cm}$.

The presence of $A$. serrensis was influenced mainly by bromeliad abundance in the understory (BR2) and by percentage of uncovered soil (\%US). The plant cover $(\% \mathrm{PC})$ exercised a negative influence, as well as the horizontal obstruction on the ground (OB1), and the litter depth (LDP). Overall, this species selected positively opened areas, with little ground vegetation. On the opposite direction, A. montensis showed positive association with the plant cover $(\% \mathrm{PC})$ and negative with uncovered soil (\%UC). Canopy height (CAH) and cover (CAC) influenced this rodent negatively, while horizontal obstruction on the ground (OB1) had a positive influence on the microhabitat use by $A$. montensis. These results indicated that $A$. montensis selected positively areas with dense vegetation, with a welldeveloped understory cover.

The scansorial rodent $D$. dorsalis showed positive association to the major distance of the small trees (T03) and negative association with the major distance of the large trees (T10). Canopy height (CAH) had a weak positive influence, while density of small trees (NT2) had a negative influence. There was a positive association with the bromeliad density on the ground (BR1). D. dorsalis was associated with regions where the large trees are close to each other, with a well-developed canopy.

Juliomys sp. presented positive association with bromeliad density in the understory (BR2) and the percentage of uncovered soil (\%US). However, the canopy height $(\mathrm{CAH})$ and canopy cover (CAC) also demonstrated a positive influence on the microhabitat use for this rodent. The dispersion of small and large trees (T03 and T10) had negative influence, while number of small trees (NT2) had a positive influence. Juliomys sp. selected positively areas with a well-developed canopy and with large density of small trees.

The arboreal marsupial G. microtarsus showed positive association with bromeliad density in the canopy (BR3), density of trees with d.b.h. lesser than $20 \mathrm{~cm}$ (NT2) and uncovered soil (\%US). Canopy height $(\mathrm{CAH})$ and cover $(\mathrm{CAC})$ had positive, although lesser, influence on the microhabitat use by this marsupial. The small tree dispersion (T03) was also important. In this sense, our results suggested that this marsupial selected positively regions with higher density and less dispersed small trees, with a well-developed canopy.

The generalist rodent $O$. flavescens was influenced mainly by canopy cover (CAC), canopy height $(\mathrm{CAH})$ and bromeliad density in the understory (BR2). The percentage of plant cover 
(\%PC) had a negative influence on the abundance of this rodent. S. angouya was positively influenced by number of shelters (SHE), horizontal obstruction at $1.5 \mathrm{~m}$ (OB3), and number of trees with d.b.h. $>40$ $\mathrm{cm}$ (NT4), and negatively by canopy cover (CAC) and bromeliad density in the understory (BR2). Finally, the terrestrial marsupial $M$. dimidiata was negatively influenced by uncovered soil (\%US), positively by bromeliad abundance on the ground (BR1), number of trees with d.b.h. between 20.1 and $40.0 \mathrm{~cm}$ (NT3), and litter depth (LDP).

\section{DISCUSSION}

In this study we verified differences on the vertical space use among some small mammals from the Araucaria Forest of southern Brazil. We also found significant differences in the microhabitat association among species, especially between the ones that use the same layers.

The Akodontini rodents registered in the area (A. montensis, A. serrensis and T. nigrita) were primarily or totally terrestrials. These rodents present morphological features that favor the exploration of ground layer, like short tails, dark hairs, thinner and longer feet and no marked differentiation between dorsal and ventral hairs (Emmons and Feer 1997, Camargo et al. 2012). Although we had found $A$. montensis in the understory, these captures occurred on traps installed on fallen logs or locations connected to the ground. Vieira and MonteiroFilho (2003) found $A$. serrensis in the understory also atop fallen logs, and P.T. Sarti (unpublished data) recorded $A$. montensis and A. paranaensis in the arboreal layer in situations with same type of facilitation. These facts suggest that some Akodontini rodents may use the stratum closest to the ground casually, when there is some structure to facilitate their displacements. Moreover, Camargo et al. (2012) suggested that patterns of vertical space use in sigmodontine rodents were not subject to major phylogenetic constraints, but to morphology tracks, like footprint shape.
Our results indicated a contrasting selection of habitat characteristics between the two Akodon species studied. In the Pampas Biome of southern Brazil, Sponchiado et al. (2012) also found differences in microhabitat use between Akodon reigi and Akodon azarae. These micro-scale differences result from a differentiation on the habitat portion used by these species, and can favor the coexistence of these phylogenetically close rodents that occurred mainly on the ground layer. In our study $A$. montensis was related to areas with great ground vegetation and litter depth, while A. serrensis was associated with opened portions of the forest.

The association found between the abundance of A. montensis and areas with great vegetation density on the ground can be related to access to food resource. Areas with great plant biomass on the ground tend to have greater invertebrate abundance (Heck Jr and Wetstone 1977), which is one of the main preys of this rodent species (Talamoni et al. 2008). The protection against terrestrial and aerial predators can also be an important factor, since the horizontal obstruction close to ground level provides vegetation cover. On a pampean agro-ecosystem of Argentina, Busch et al. (2001) suggested that the association between $A$. azarae and the Baccharis sp. shrubs can be related to the fact that these plant species offer cover and reduce predation risk, mainly by aerial predators.

In our study, A. montensis was negatively influenced by the canopy cover, corroborating the results found by Püttker et al. (2008) on the southeastern Brazilian Atlantic Forest. On the other hand, in another area of Araucaria Forest in southern Brazil, Dalmagro and Vieira (2005) found a positive influence of the canopy cover on the microhabitat use by $A$. montensis, contradicting our results. However, the fragment area studied by Dalmagro and Vieira (2005) was characterized by a poorly developed understory. The absence of a consistent plant cover on the ground could modify 
the microhabitat association in this area studied by Dalmagro and Vieira (2005), forcing this rodent to use areas with a well-developed canopy cover. This suggests that differences on the vegetation structure between areas can lead to differences in microhabitat association.

The association with opened area found for $A$. serrensis can be due to the fact that stems and shrubs interfere in the movement of these strictly terrestrial rodents. The noise produced by the movement in a dense area can reveal the presence of the animal to predators, making the rodent more susceptible to predation (Simonetti 1989). On the other hand, areas with lesser plant cover tend to not provide adequate shelter and protection. It's possible that the dark hair color of $A$. serrensis offers a defensive strategy for this rodent. In an artificial experiment, Simonetti (1989) reported that rodents of the genus Akodon frequently present a "freezing" behavior when they felt the silhouette of a potential predator. In this sense, this rodent species can use the dark color as a camouflage, standing unmoved on an area with little vegetation that tends to also be dark.

On the Pró-Mata area the rodent $D$. dorsalis selected positively areas with great distance between small trees (d.b.h. from $3 \mathrm{~cm}$ to $10 \mathrm{~cm}$ ) and short distances between large trees (d.b.h. upper than 10 $\mathrm{cm}$ ). Dalmagro and Vieira (2005) found this rodent species associated to a close distance of the nearest tree (except $A$. angustifolia) on the Araucaria Forest. These authors suggested that this can be due to fruit availability on the ground. The association that we found in Pró-Mata can also be related to the access of the understory, frequently used by this scansorial rodent. The captures of $D$. dorsalis in the understory usually occurred on large trees and logs. The use of understory can be a strategy of predation escape (e.g. Abreu et al. 2010).

The microhabitat variables related to canopy were very important to the arboreal rodent Juliomys sp. The association between this rodent and the great density and closest trees and shrubs is possibly related to the access and movement on the arboreal layers. Cunha and Vieira (2002) showed that stems with lesser diameter were the most used for arboreal locomotion by didelphid marsupials in southeastern Brazil. According to these authors, the small mammals tended to distribute their body mass on different stems, with each member and the prehensile tail holding different supports. Furthermore, the fact that these trees and shrubs are close to each other can favor the connectivity between them and develop structures that facilitate arboreal movements, making the habitat more vertically complex (Rader and Krockenberger 2006).

The variable associations found for $G$. microtarsus are also, probably, related to arboreal access and movement. The weak association between this marsupial and the canopy height can be related to a positive selection of the understory. This intermediate portion of vertical habitat can provide protection against terrestrial and aerial predators (e.g. Sushma and Singh 2006). Although we found $G$. microtarsus in all the layers analyzed, the majority of captures occurred in the understory, followed by canopy.

We detected an association between the abundance of bromeliad on arboreal layers and the microhabitat utilization of the two arboreal species studied, G. microtarsus and Juliomys sp., and the vertical habitat generalist rodent $O$. flavescens. The terrestrial marsupial $M$. dimidiata was also related to the abundance of bromeliad on the ground (below $1 \mathrm{~m}$ ). Lacher Jr and Alho (1989) found that the abundance of the rodent Thrichomys pachyurus ( $=T$. apereoides) was influenced by the presence of bromeliads. This is the only study performed in Brazilian territory that used the bromeliad abundance as a microhabitat variable. The bromeliads accumulate water from the rains in the rosettes formed by leaves, and provides an adequate microhabitat for invertebrates (Mestre et al. 2001), so, it can be an important source of food resources (invertebrates) and water on the arboreal layers. 
This is the first study to provide information about the habitat use of Juliomys sp., a poorly known rodent genus. Even though this rodent is very difficult to capture, 15 individuals with 18 captures were caught during this work. This fact provides evidences about its arboreal habitat use and association with small vegetation. These ecological data can help answer biogeographic questions about habitat use and distribution of Juliomys rodents (Pavan and Leite 2011). The correct identification of this rodent species was not possible, but based on their cranio-dental morphology we know that this is not the species found by Paresque et al. (2009) in the National Park of Aparados da Serra, and probably is not the Juliomys pictipes.

Finally, we suggest that vertical space use and microhabitat associations are part of a synergic mechanism to favor the small mammals' coexistence in the Araucaria Forest of southern Brazil. These two factors must be considered in habitat use studies in Neotropical forests.

\section{ACKNOWLEDGEMENTS}

We would like to thank Nathalia dos Santos Freitas, Guilherme Walter Schmitz, Paulo Tomasi Sarti, Tais Monero, Simone Oliveira, Cristiane Forgiarini and Fábio Oliveira for the field help. Additional acknowledgements go to Maury R. Abreu and Cassandra A.S.L. Abreu who provided financial and logistic support for the surveys and to Geraldo S. Freitas and Tricia K. Santos for their logistic support. Dra. Luciane Crossetti helped on the ordination analysis. We would also like to thank Dr. Alexandre U. Christoff and Dr. Victor H. Valliati, for their help with the identification of the small mammals. Our thank you also extends to all the workers on the Pró-Mata for the help, to the colleagues of the "Laboratório de Ecologia de Mamíferos" for financial help. We thank two anonymous referees for their comments and suggestions on an earlier version of this manuscript. Support for this research was provided by Coordenação de Aperfeiçoamento de Pessoal de Nível Superior (CAPES) with PROSUP master grant to MSLA. UNISINOS provided local facilities and part of the equipment. This research was authorized by Instituto Brasileiro do Meio Ambiente e dos Recursos Naturais Renováveis (IBAMA).

\section{RESUMO}

Apesar dos avanços nas técnicas para pesquisa de pequenos mamíferos arborícolas, dados ecológicos detalhados, tal como padrões de uso do habitat, são praticamente inexistentes para muitas espécies. Utilizando 150 armadilhas de captura viva instaladas no solo, sub-bosque $(1,0-5,0 \mathrm{~m})$ e dossel $(>5,0 \mathrm{~m})$ nós investigamos padrões no uso do espaço arbóreo e terrestre por pequenos mamíferos em uma Floresta com Araucária no sul do Brasil (29²9’08”'S; 50¹2’26”W). Nós medimos 19 variáveis de micro-habitat que poderiam potencialmente influenciar a abundância de tais mamíferos em cada estação de captura. Os resultados indicaram que Akodon montensis e A. serrensis foram principalmente terrestres. Delomys dorsalis também foi terrestre, mas também utilizou o sub-bosque (17,24\% das capturas). Juliomys sp. e Gracilinanus microtarsus foram os pequenos mamíferos mais arborícolas registrados. A. montensis esteve associado com vegetação densa, enquanto $A$. serrensis selecionou positivamente áreas abertas. Juliomys sp. e G. microtarsus estiveram associados a variáveis de micro-habitat relacionadas ao acesso e movimentação no dossel. Além disso, bromélias no estrato arbóreo foram um importante fator para estas duas espécies arborícolas. Este é o primeiro estudo a reportar associações de micro-habitat por Juliomys sp. e A. serrensis, e nós demonstramos que a estratificação vertical e o uso do micro-habitat são mecanismos sinergéticos em determinar o uso do habitat por pequenos mamíferos na Floresta com Araucária do sul do Brasil.

Palavras-chave: Didelphimorphia, micro-habitat, mamíferos neotropicais, Rodentia, estratificação vertical. 


\section{REFERENCES}

ABReu MSL, WieliczKo AR, MEsquita A AND VieIRA EM. 2010. Consumo de pequenos mamíferos por canídeos simpátricos do sul do Brasil: sobreposição de nichos e seleção de presas. Neotrop Biol Conserv 5: 16-23.

Adler GH, Carvajal A, Davis-Foust SL and DitTel JW. 2012. Habitat associations of opossums and rodents in a lowland forest in French Guiana. Mamm Biol 77: 84-89.

BorCARD D, GILlET F AND LEGENDRE P. 2011. Numerical ecology with R, New York: Springer, 306 p.

Busch M, Mino MH, Dadon JR AND Hodara K. 2001 Habitat selection by Akodon azarae and Calomys laucha (Rodentia, Muridae) in pampean agroecosystems. Mammalia 65: 29-48.

Cademartori CV, Marques RV and Pacheco SM. 2008. Estratificação vertical no uso do espaço por pequenos mamíferos (Rodentia, Sigmodontinae) em área de Floresta Ombrófila Mista, RS, Brasil. Rev Zooc 10: 187-194.

Camargo NF, Ribeiro JF, Gurgel-Gonçalves R, Palma ART, MENDONÇA AF AND VIEIRA EM. 2012. Is footprint shape a good predictor of arboreality in sigmodontine rodents from a neotropical savanna? Acta Theriol 57: 261-267.

CERQUEIRA R AND FREITAS SR. 1999. A new study method of microhabitat structure of small mammals. Rev Bras Biol 59: 219-223.

Charles-Dominique $\mathrm{P}$, ATRAMENTOWICZ M, CharlesDominique M, GÉRARD H, HLANDIK A, HLANDIK CM AND PRÉvOST MF. 1981. Les mammiferes frugivores arboricoles nocturnes d'une forest guyanaise: inter-relations plantes-animaux. Rev Ecol - Terre Vie 35: 341-436.

CUNHA AA AND VIEIRA MV. 2002. Support diameter, incline, and vertical movements of four didelphid marsupials in the Atlantic forest of Brazil. J Zool 258: 419-426.

DAlMagro AD AND VIEIRA EM. 2005. Patterns of habitat utilization of small rodents in an area of Araucaria forest in Southern Brazil. Austral Ecol 30: 353-362.

Delciellos AC, LORETTO D AND VieirA MV. 2006. Novos métodos no estudo da estratificação vertical de marsupiais neotropicais. Oecol Bras 10: 135-153.

DinUCCI KL, Silva HS AND GeISE L. 2008. Preferência de micro-habitat de quatro espécies de marsupiais (Mammalia, Didelphimorphia) da Mata Atlântica do estado do Rio de Janeiro e considerações sobre a metodologia. In: Reis NR et al. (Eds), Ecologia de mamíferos, Rio de Janeiro: Technical Books, p 19-31.

EMMONS LH AND FEER F. 1997. Neotropical rainforest mammals: a field guide, $2^{\text {nd }}$ ed., Chicago: University of Chicago, $307 \mathrm{p}$.

Frazer GW, CANHAM CD AND LERTZMAN KP. 1999. Gap Light Analyzer (GLA): imaging software to extract canopy structure and gap light transmission indices from truecolour fisheye photographs, user's manual and program documentation. Copyright (C) 1999: Simon Fraser University, Burnaby, British Columbia, and the Institute of Ecosystem Studies, Millbrook, New York.
Freitas SR, CERQueIra R AND VIEIRA MV. 2002. A device and standard variables to describe microhabitat structure of small mammals based on plant cover. Braz J Biol 62: 795-800.

GRAIPEL ME. 2003. A simple ground-based method for trapping small mammals in the forest canopy. Mastozool Neotrop 10: 177-181.

GRAIPEL ME, CHEREM JJ, MONTEIRO-FILHO ELA AND GLOCK L. 2006. Dinâmica populacional de marsupiais e roedores no Parque Municipal da Lagoa do Peri, Ilha de Santa Catarina, sul do Brasil. Mastozool Neotrop 13: 31-49.

Graipel ME, Miller PRM AND Glock L. 2003. Padrão de atividade de Akodon montensis e Oryzomys russatus na Reserva Volta Velha, Santa Catarina, sul do Brasil. Mastozool Neotrop 10: 255-260.

GRELLE CEV. 2003. Forest structure and vertical stratification of small mammals in a secondary Atlantic Forest, southeastern Brazil. Stud Neotrop Fauna E 38: 81-85.

HAIR JR JF, BLACK WC, BABIN BJ AND ANDERSON RE. 2010 Multivariate data analysis, $7^{\text {th }}$ ed., Upper Saddle River: Prentice Hall, 816 p.

HANNIBAL W AND CÁCERES NC. 2010. Use of vertical space by small mammals in gallery forest and woodland savannah in south-western Brazil. Mammalia 74: 247-255.

HeCK JR KL AND WeTSTONE GS. 1977. Habitat complexity and invertebrate species richness and abundance in tropical seagrass meadows. J Biogeogr 4: 135-142.

IOB G AND VIEIRA EM. 2008. Seed predation of Araucaria angustifolia (Araucariaceae) in the Brazilian Araucaria Forest: influence of deposition site and comparative role of small and "large" mammals. Plant Ecol 198: 185-196.

KAYS R AND ALLison A. 2001. Arboreal tropical forest vertebrates: current knowledge and research trends. Plant Ecol 153: 109-120.

LACHER JR TE AND ALHO CJR. 1989. Microhabitat use among small mammals in the Brazilian Pantanal. J Mammal 70: 396-401.

LAMBERT TD, MALCOLM JR AND ZIMMERMAN BL. 2005 Variation in small mammal species richness by trap height and trap type in southeastern Amazonia. J Mammal 86: 982-990.

LEGENDRE P AND LEGENDRE L. 1998. Numerical ecology, $2^{\text {nd }}$ English ed., The Netherlands: Elsevier Science B.V., 853 p.

LeIte YLR, COSTA LP AND STALlingS JR. 1996. Diet and vertical space use of three sympatric opossums in a Brazilian Atlantic forest reserve. J Trop Ecol 12: 435-440.

LEPŠ J AND ŠMILAUER P. 1999. Multivariate analysis of ecological data, České Budějovice: University of South Bohemia, $110 \mathrm{p}$

Lima DO, AZAmbuja BO, CAMIlotTi VL AND CÁCERES NC. 2010. Small mammal community structure and microhabitat use in the austral bundary of the Atlantic Forest, Brazil. Zoologia 27: 99-105.

MÄHLER JR JKF AND LAROCCA JF. 2009. Fitofisionomias, desmatamento e fragmentação da Floresta com Araucária. In: Fonseca $\mathrm{CR}$ et al. (Eds), Floresta com araucária: ecologia, conservação e desenvolvimento sustentável, Ribeirão Preto: Holos, p. 243-252. 
Mestre LAM, ARANHA JMR AND ESPER MLP. 2001. Macroinvertebrate fauna associated to the bromeliad Vriesea inflate of the Atlantic Forest (Paraná State, Southern Brazil). Braz Arch Biol Techn 44: 89-94.

MURÚA R AND GONZÁLEZ LA. 1982. Microhabitat selection in two chilean cricetid rodents. Oecologia 52: 12-15.

NAXARA L, PINOTTI BT AND PARDINI R. 2009. Seasonal microhabitat selection by terrestrial rodents in and oldgrowth Atlantic forest. J Mammal 90: 404-415.

OKSANEn J, Blanchet FG, Kindt R, LEgEndRe P, O'Hara RB, Simpson GL, Solymos P, Stevens MH AND WAGNER H. 2001. Vegan: community ecology package. R package version 1.17-12. <http://CRAN.R- project.org/ package= $=$ egan $>$ Accessed 2 Nov 2011 .

Paglia AP ET AL. 2012. Lista anotada de mamíferos do Brasil / Annotated checklist of Brazilian mammals. $2^{\text {a }}$ edição $/ 2^{\text {nd }}$ edition. Occas Pap Cons Biol 6, Conservation International, Arlington, VA, $76 \mathrm{p}$.

Paresque R, Christoff AU AND Fagundes V. 2009. Karyology of the Atlantic forest rodent Juliomys (Cricetidae): a new karyotype from southern Brazil. Genet Mol Biol 32: 301-305.

PAVAN SE AND LEITE YLR. 2011. Morphological diagnosis and geographic distribution of Atlantic Forest red-rumped mice of the genus Juliomys (Rodentia: Sigmodontinae). Zoologia 28: 663-672.

Prevedello JA, Ferreira P, Papi BS, Loretto D AND VIEIRA MV. 2008. Uso do espaço vertical por pequenos mamíferos no Parque Nacional Serra dos Órgãos, RJ: um estudo de 10 anos utilizando três métodos de amostragem. Espac Geog 11: 95-119.

PÜTTKER T, PARDINI R, MEYER-LUCHT Y AND SOMMER S. 2008. Responses of five small mammal species to micro-scale variations in vegetation structure in secondary Atlantic Forest remnants, Brazil. BioMed Central Ecol 8. $<$ http://www.biomedcentral.com/1472-6785/8/9>. Accessed 27 Jul 2011.

RADER R AND KROCKEnBERger A. 2006. Does resource availability govern vertical stratification of small mammals in an Australian lowland tropical rainforest? Wildlife Res 33: 571-576.
RIBEIRO JF AND VIEIRA EM. 2012. Os mamíferos e a floresta com Araucária brasileira: riqueza de espécies e relevância para a conservação. In: Freitas TRO and Vieira EM (Eds), Mamíferos do Brasil: genética, sistemática, ecologia e conservação, Vol. II, Rio de Janeiro: Sociedade Brasileira de Mastozoologia, p. 164-176.

SCHOENER TW. 1974. Resource partitioning in ecological communities. Science 185: 27-39.

Sikes RS, GANNON WL AND THE ANIMAL CARE AND USE COMMITTEE OF THE AMERICAN SOCIETY OF MAMMALOGISTS. 2011. Guidelines of the American Society of Mammalogists for the use of wild mammals in research. J Mammal 92: 235-253.

SimONETTI JA. 1989. Microhabitat use by small mammals in central Chile. Oikos 56: 309-318.

Sponchiado J, Melo GL AND CÁCERES NC. 2012. Habitat selection by small mammals in Brazilian Pampas biome. J Nat Hist 46: 1321-1335.

Sushma HS AND SingH M. 2006. Resource partitioning and interspecific interactions among sympatric rain forest arboreal mammals of the Western Ghats, India. Behav Ecol 17: 479-490.

TAlamoni SA, Couto D, Cordeiro JR DA AND Diniz FM. 2008. Diet of some species of Neotropical small mammals. Mamm Biol 73: 337-341.

VIEIRA EM AND BAUMGARTEN LC. 1995. Daily activity patterns of small mammals in a Cerrado area from central Brazil. J Trop Ecol 11: 255-262.

Vieira EM, Iob G, BRIANI DC AND PALMA ART. 2005. Microhabitat selection and daily movements of two rodents (Necromys lasiurus and Oryzomys scotti) in Brazilian Cerrado, as revealed by a spool-and-line device. Mamm Biol 70: 359-365.

VIEIRA EM AND MONTEIRO-FILHO ELA. 2003. Vertical stratification of small mammals in the Atlantic rain forest of southeastern Brazil. J Trop Ecol 19: 501-507.

ZAR JH. 1996. Biostatistical analysis, $5^{\text {th }}$ ed, New Jersey: Prentice Hall, 960 p. 